\title{
Onychomadesis and potential association with HFMD outbreak in a kindergarten in Hubei province, China, 2017
}

Dan $\mathrm{Li}^{1,2,3 \dagger}$, Yang Wu${ }^{2 \dagger}$, Xuesen Xing ${ }^{2 \dagger}$, Jigui Huang ${ }^{4}$, Anlu Mao ${ }^{4}$, Tian Liu ${ }^{4}$, Ping Rao ${ }^{5}$, Wei Qin ${ }^{6}$, Lijie Zhang ${ }^{5}$, Luzhao Feng ${ }^{7}$, Shangren Gao ${ }^{1^{*}}$ and Xuhua Guan ${ }^{2^{*}}$

\begin{abstract}
Background: In 2017, an outbreak of onychomadesis occurred in kindergarten H, Hubei province, China. We investigated the field to learn about the magnitude and reason of the outbreak.

Methods: The case definition was that a child with onychomadesis or transverse ridging (Beau's line) in fingernails and toenails without previous traumatic or systemic disease in kindergarten H from Sep. 1st to Nov. 30th, 2017. A retrospective cohort study was carried out to analyze the epidemiological relationship between onychomadesis and the hand-foot-mouth disease (HFMD) in Primary Class \#2, kindergarten H. We also performed a serological survey for neutralizing antibodies against coxsackie virus A6 (CVA6), coxsackie virus A10 (CVA10) among 15 cases and six healthy children in the kindergarten. Meanwhile, some children were carried out with routine blood, fungal microscopic and microelement tests. Indoor environment examinations had been done for all classes.

Results: A total of 20 cases were identified in Kindergarten H. Seventy-five percent (15/20) cases occurred in Primary Class \#2. Fifty-five percent of the cases (11/20) had suffered from HFMD within two months. The median time between onychomadesis and HFMD was 45 days (ranging from 31 to 58 days). A retrospective cohort study in Primary Class \#2 showed the attack rate was $90.0 \%$ among 10 children who suffered from HFMD in the past two months compared to 30.0\% among 20 children who didn't (Rate Ratio [RR] $=3.0$, 95\% Confidence Interval [Cl] $=1.5-$ 6.0). The positive rates of neutralizing antibodies were $66.7 \%$ for CVA6 and $26.7 \%$ for CVA10 in tested cases. The result of routine blood, fungal microscopic, microelements tests were normal in cases. The indicators of environment were within the normal range.
\end{abstract}

Conclusion: The results of this study suggested that the outbreak of onychomadesis in Hubei province was probably associated with HFMD epidemic within two months.

Keywords: Onychomadesis, Hand, Food and mouth disease, Outbreak

\section{Background}

Onychomadesis is the shedding of the nails beginning at the proximal end, possibly caused by the temporary arrest of the function of the nail matrix, and can affect both fingernails and toenails $[1,2]$. Nail matrix arrest may result in a variety of changes, including nail

\footnotetext{
* Correspondence: 3539263434@qq.com; 552371433@qq.com

${ }^{\dagger}$ Dan Li, Yang Wu and Xuesen Xing contributed equally to this work.

${ }^{1}$ Division of Infectious Disease, Jingmen Center for Disease Control and

Prevention, Jingmen 448000, Hubei, China

${ }^{2}$ Division of Infectious Disease, Hubei Provincial Center for Disease Control and Prevention, Wuhan 430079, China

Full list of author information is available at the end of the article
}

shedding (onychomadesis) and transverse ridging (Beau's lines) [3]. It is a rare disorder in children, and cases were considered to be idiopathic or acquired [3]. HFDM viruses are potential risk factors of onychomadesis in children [4-19]. Onychomadesis after HFMD was first reported in five children in Chicago, USA, 2000 [4]. A similar report of four children with onychomadesis published in Liège, Belgium, 2001 [5]. Onychomadesis outbreaks associated with HFMD had also been reported in Spain [3, 6-11], Finland [12, 13], Taiwan [14], Greece [15], Japan [16]. In the mainland China, an onychomadesis outbreak after HFMD occured in Hangzhou in 2016

(c) The Author(s). 2019 Open Access This article is distributed under the terms of the Creative Commons Attribution 4.0 International License (http://creativecommons.org/licenses/by/4.0/), which permits unrestricted use, distribution, and 


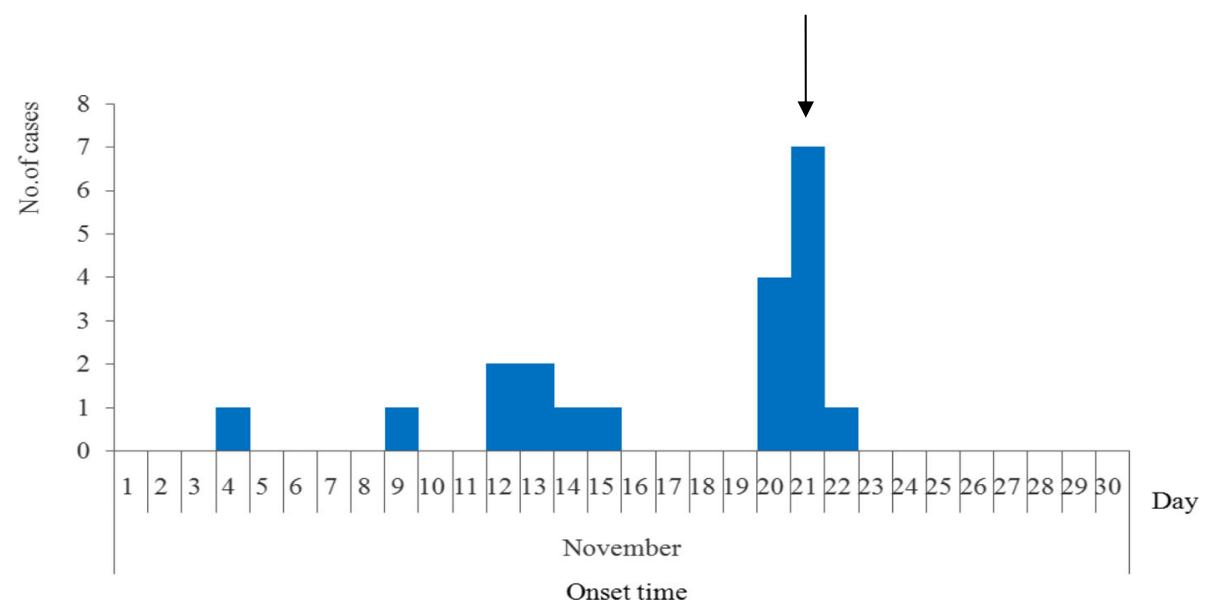

Fig. 1 The epidemic curve of the onychomadesis outbreak in Kindergarten H, Hubei province, 2017

[17], and 43.1\% HFMD cases suffered from onychomadesis between the 3th and 8th week after onset in an HFMD outbreak in Beijing, 2015 [18]. Molecular characterization of the etiologic agent involved in onychomadesis after HFMD, remains controversial [19]. Onychomadesis has a strong association with CVA6 and CVA10, and other serotypes such as coxsackie virus B1 (CVB1), coxsackie virus B2 (CVB2), coxsackie virus A5 (CVA5), enterovirus 71 (EV71), coxsackie virus A16 (CVA16), enterovirus 9 (E9) [7-19]. HFMD is a common viral illness that usually affects infants and children younger than five years old. The main symptoms are fever, sore throat, general malaise, and vesicular eruptions on the palms of the hands, oral mucosa, soles of the feet, and tongue [10]. 7,200,092 probable cases of HFMD were reported in notifiable disease monitoring system of China during 2008-2012, and EV71 predominated in laboratory-confirmed cases, which accounted for $93 \%$ of fatal cases, $80 \%$ of severe cases, and $45 \%$ of mild cases [20]. EV71, CVA16, and other enteroviruses co-circulated during 2008-2012 in China [20-22]. The proportions were $45 \%$ for other enteroviruses, $41 \%$ for EV71, and $14 \%$ for CVA16 in laboratory-confirmed HFMD cases in China in 2017, while the proportions were $76 \%$ for other enteroviruses, $10 \%$ for EV71, and $15 \%$ for CVA16 in Hubei province in 2017 according to the notifiable disease monitoring system of China. Eleven children suffered from onychomadesis were reported to Hubei provincial center for disease control and prevention in the same class in Kindergarten $\mathrm{H}$ in Songzi County on Nov.21th, 2017. We immediately conducted the investigation to find out the magnitude and potential reason of this onychomadesis outbreak.

\section{Methods}

Epidemiological investigations

A case was defined as a child with onychomadesis or Beau's line in fingernails and toenails without previous

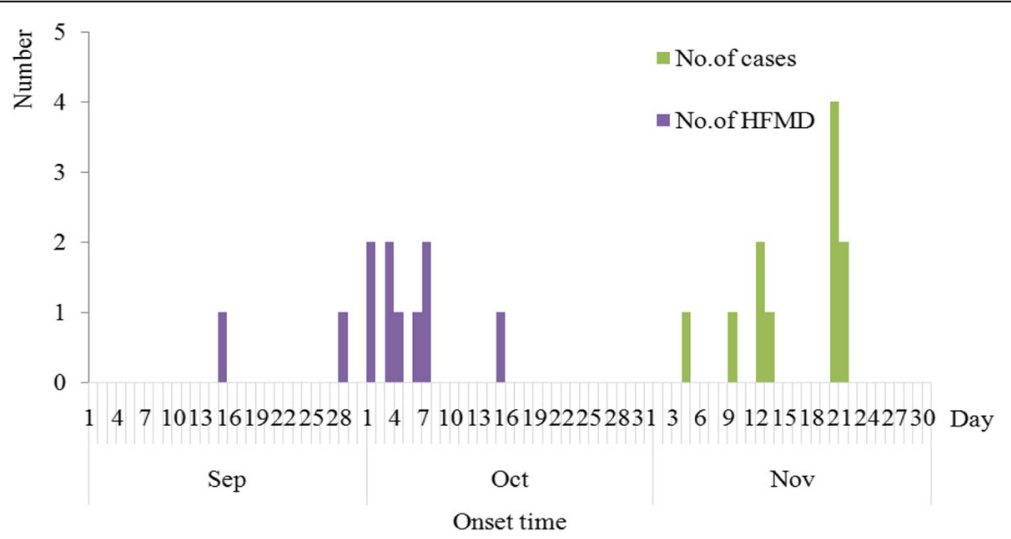

Fig. 2 The onset time of the onychomadesis and HFMD from Sep to Nov in Kindergarten H, Hubei province, 2017 


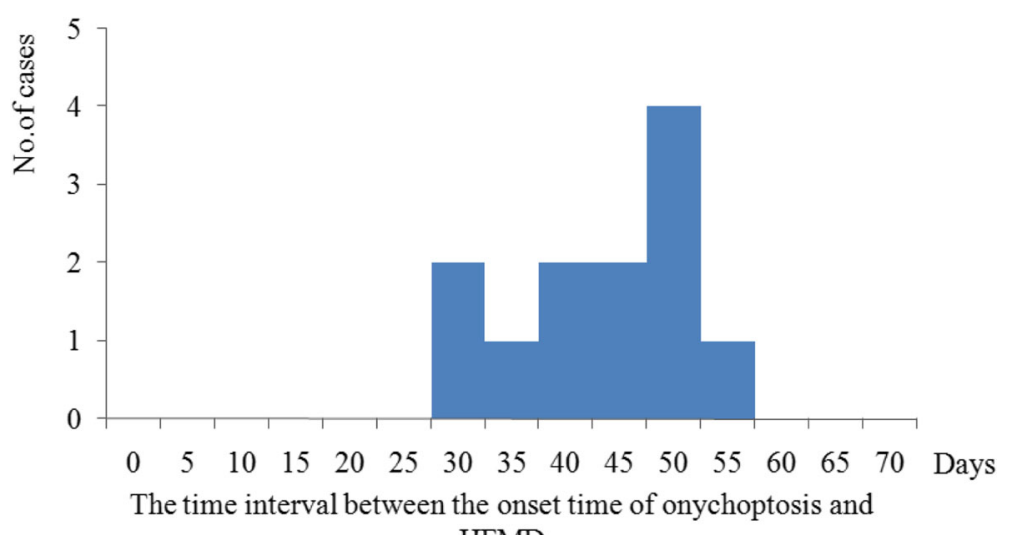

HFMD

Fig. 3 The time interval between the onset time of onychomadesis and HFMD in Kindergarten H, Hubei province, 2017

traumatic or systemic disease in Kindergarten H, Songzi County, Hubei province from Sep. 1st to Nov. 30th, 2017. The diagnosis was conducted through on-site checking of nails by pediatricians and dermatologists, combined with interviewing kindergarten staffs, and reviewing routine health and absence records of children. Questionnaires were used to collect the information about the onset, diagnosis and treatment, illness in the last two months, behavior habits and nutrition condition. Meanwhile, we asked if similar cases had occurred in four nearby kindergartens in the county. A retrospective cohort study was under-taken to analyze the relationship between onychomadesis and the prevalence of HFMD in recent two months in Primary Class \#2 in Kindergarten H. EXCEL2007 was used to collate data and draw the epidemic curve, and SPSS13.0 was used to analyze the data.

\section{Laboratory tests}

Blood samples of six cases and six healthy children were collected to identify their microelement status including calcium, iron, zinc, lead, cadmium, copper and magnesium. The indoor environment of all classes in Kindergarten $\mathrm{H}$ was examined with the indicators of formaldehyde, benzene, toluene, and xylene. Six pieces of plasticines used by cases were detected for the lead. Fungal microscopic examinations of nail smear samples were taken. We collected the anal swabs and serum specimens from 15 cases and 6 healthy children. Viral RNA was extracted using a QIAamp Viral RNA Mini Kit (Qiagen, Valencia, CA, USA). We tested RNA from each sample for sequencing VP1 (viral protein 1) gene of enterovirus including EV71, CA16, CA6 and CA10 by realtime reverse transcriptase-polymerase chain reaction (RT-PCR) using fluorescent PCR detection kits for HFMD viral RNA (Shuoshi Biotechnology company, Jiangsu, China). Neutralizing antibody tests of CA6 and CA10 were performed for serum specimens as described [23]. A neutralizing titer of $\geq 1: 16$ was considered as a threshold for positivity [23, 24].

\section{Results}

\section{Descriptive epidemiology}

A total of 20 cases were identified in Kindergarten $\mathrm{H}$ which has 250 children in our study. The attack rate was $8.0 \%(20 / 250)$, and there was no severe or death case. All 20 cases (100.0\%) has occurred onychomadesis and 4 cases $(20.0 \%)$ also had Beau's line in their nails. Onychomadesis started from the proximal deck and gradually developed to the distal deck. The numbers of affected fingers or toes were between one and nine with the average two. Eighteen and two cases had unhealthy fingernails and toenails respectively, while two cases had unhealthy fingernails and toenails simultaneously. The onychomadesis cases occurred between Nov. 4th and Nov. 22th as shown in Fig. 1. The attack rates of male and female children in kindergartens were $6.7 \%(8 / 118)$ and $9.1 \%(12 / 132)$ respectively, without statistical difference $\left(x^{2}=0.45, P>0.05\right)$. The median age of the $20 \mathrm{pa}$ tients was 3 years old (range, 3-4 years). There were seven classes in kindergarten $\mathrm{H}$, and three of them had cases with onychomadesis. $75.0 \%(15 / 20)$ cases occurred

Table 1 Analysis of risk factor of onychomadesis in Primary Class \#2 of Kindergarten H, Hubei province, 2017

\begin{tabular}{lllll}
\hline Factor: Suffered from HFMD in the past two months & No. of cases & Overall No. & Attack rate (\%) & $R R(95 \%$ Cl) \\
\hline Yes & 9 & 10 & 90.0 & $3.0(1.5-6.0)$ \\
No & 6 & 20 & 30.0 & Ref. \\
\hline
\end{tabular}


Table 2 Results of HFMD neutralization antibody test in Kindergarten H, Hubei province, 2017

\begin{tabular}{lcccc}
\hline $\begin{array}{l}\text { Source of } \\
\text { specimens }\end{array}$ & $\begin{array}{l}\text { No. of } \\
\text { specimens }\end{array}$ & \multicolumn{3}{l}{ Positive No. for neutralization antibody test } \\
\cline { 3 - 5 } & 15 & 10 & CVA10 & CVA6 or CVA10 \\
\hline Cases & 6 & 4 & 4 & 10 \\
Healthy children & & 3 & 6 \\
\hline
\end{tabular}

in Primary Class \#2. According to the retrospective interview, $55.0 \%$ of the cases $(11 / 20)$ had suffered from HFMD characterized by fever (72.8\%) and vesicular eruptions $(100.0 \%)$ on hands or feet or in the mouth, within two months before the onset of onychomadesis. The median time between onychomadesis and HFMD was 45 days (ranging from 31 to 58 days) (Figs. 2, 3).

\section{Analysis of risk factors}

A retrospective cohort study in Primary Class \#2 showed the attack rate was $90.0 \%$ among ten who suffered from HFMD in recent two months compared to $30.0 \%$ among
20 who didn't (Rate Ratio $[R R]=3.0,95 \%$ Confidence Interval $[\mathrm{CI}]=1.5-6.0)($ Table 1$)$.

\section{Laboratory test results}

The positive rates of neutralizing antibodies were $66.7 \%$ (10/15) for CVA6 and 26.7\% (4/15) for CVA10 in tested cases. $66.7 \%(10 / 15)$ of tested cases and $100 \%(6 / 6)$ tested healthy children were positive for CVA6 or CAV10 neutralization antibody test, without statistical difference (Fisher's exact probability method, $P>0.05$ ) (Table 2). All anal swabs samples were negative for HFMD nucleic acid test. Indicators of microelement, routine blood, fungal microscopic and environment of

Table 3 Reported outbreaks of onychomadesis associated with HFMD

\begin{tabular}{|c|c|c|}
\hline Study & Title & District \\
\hline $\begin{array}{l}\text { Clementz GC et al. } \\
2000[4] .\end{array}$ & Nail matrix arrest following hand-foot-mouth disease: a report of five children. & Chicago, USA \\
\hline $\begin{array}{l}\text { Bernier } V \text { et al. } 2001 \\
\text { [5]. }\end{array}$ & Nail matrix arrest in the course of hand, foot and mouth disease. & $\begin{array}{l}\text { Liège, Belgium; } \\
\text { Bordeaux, France }\end{array}$ \\
\hline $\begin{array}{l}\text { Salazar A et al. } 2008 \\
\text { [3]. }\end{array}$ & Onychomadesis outbreak in Valencia, Spain, June 2008. & Valencia, Spain \\
\hline $\begin{array}{l}\text { Redondo Granado MJ } \\
\text { et al. } 2009 \text { [6]. }\end{array}$ & Brote de onicomadesis posvírica en Valladolid. & Valladolid, Spain \\
\hline $\begin{array}{l}\text { Osterback R et al. } 2009 \\
\text { [12]. }\end{array}$ & Coxsackievirus A6 and hand, foot, and mouth disease, Finland. & Finland \\
\hline $\begin{array}{l}\text { Blomqvist S et al. } 2010 \\
\text { [13]. }\end{array}$ & $\begin{array}{l}\text { Co-circulation of coxsackieviruses A6 and A10 in hand, foot and mouth disease outbreak in } \\
\text { Finland. }\end{array}$ & Finland \\
\hline $\begin{array}{l}\text { Cabrerizo M et al. } 2009 \\
\text { [7]. }\end{array}$ & Onychomadesis after a hand, foot, and mouth disease outbreak in Spain, 2009. & La Coruna, Spain \\
\hline $\begin{array}{l}\text { Guimbao J et al. } 2010 \\
\text { [8]. }\end{array}$ & Onychomadesis outbreak linked to hand, foot, and mouth disease, Spain, July 2008. & Saragossa, Spain \\
\hline Davia JL et al. 2011 [9]. & $\begin{array}{l}\text { Onychomadesis outbreak in Valencia, Spain associated with hand, foot, and mouth disease caused } \\
\text { by enteroviruses. }\end{array}$ & Valencia, Spain \\
\hline $\begin{array}{l}\text { Bracho MA et al. } 2011 \\
\text { [10]. }\end{array}$ & Enterovirus co-infections and onychomadesis after hand, foot, and mouth disease, Spain, 2008. & Valencia, Spain \\
\hline Wei SH et al. 2011 [14]. & $\begin{array}{l}\text { An outbreak of coxsackievirus A6 hand, foot, and mouth disease associated with onychomadesis } \\
\text { in Taiwan, } 2010 .\end{array}$ & Taiwan, China \\
\hline $\begin{array}{l}\text { Navarro Moreno E } \\
\text { et al. } 2014[11] .\end{array}$ & $\begin{array}{l}\text { Outbreak of hand, foot and mouth disease with onychomadesis caused by Coxsackie virus A16 in } \\
\text { Granada. }\end{array}$ & Granada, Spain \\
\hline $\begin{array}{l}\text { Miyamoto A et al. } 2014 \\
\text { [16]. }\end{array}$ & $\begin{array}{l}\text { An outbreak of hand-foot-and-mouth diseasemimicking chicken pox, with a frequent association } \\
\text { of onychomadesis in Japan in 2009: a new phenotype caused by coxsackievirus A6. }\end{array}$ & Oita, Japan \\
\hline $\begin{array}{l}\text { Apalla Z et al. } 2015 \\
\text { [15]. }\end{array}$ & $\begin{array}{l}\text { Onychomadesis after hand-foot-and-mouth diseaseoutbreak in northern Greece: case series and } \\
\text { brief review of the literature. }\end{array}$ & Northern Greece \\
\hline Kao QJ et al. 2016 [17]. & $\begin{array}{l}\text { An outbreak of coxsackievirus A6 hand, foot, and mouth disease associated with onychomadesis } \\
\text { in Hangzhou. }\end{array}$ & Hangzhou, China \\
\hline Li J et al. 2018 [18]. & $\begin{array}{l}\text { An outbreak of Coxsackievirus A6-associated hand, foot, and mouth disease in a kindergarten in } \\
\text { Beijing in } 2015 \text {. }\end{array}$ & Beijing, China \\
\hline
\end{tabular}


tested cases were within the normal range (Additional file 1 Table S1).

\section{Discussion}

8.0\% (20/250) of children suffered from onychomadesis in kindergarten $\mathrm{H}$, Songzi county, Hubei province, from Sep 1 to Nov 30 in 2017. Fifty-five percent of the cases $(11 / 20)$ had suffered from HFMD within two months before onychomadesis. The median time between onychomadesis and HFMD was 45 days (ranging from 31 to 58 days). A retrospective cohort study in primary class \#2 showed that children who had suffered from HFMD within two months had three times of the risk of onychomadesis. The positive rates of neutralizing antibodies were $66.7 \%$ for CVA6 and $50.0 \%$ for CVA10. The results of this study suggested that the onychomadesis epidemic occurred in Hubei province was probably associated with HFMD within two months prior to the onset of the disease. In our study, the factors of idiopathic, medicine, fungal microscopic, microelement, and environment for onychomadesis were almost excluded. The symptoms of cases were similar with other onychomadesis outbreak after HFMD (Table 3) [3-18]. The median time between onychomadesis and HFMD in this outbreak was 45 days (ranging from 31 to 58 days), which was also similar with other references except for a little shorter than 36-69 days in an onychomadesis outbreak, Spain, 2009 [7]. $66.7 \%(10 / 15)$ of the cases were positive for CVA6 or CAV10 neutralization test, which was similar with $65.9 \%$ $(29 / 44)$ positive in an onychomadesis outbreak, Spain, 2008 [9]

The positive rate of neutralizing antibodies was 58\% for CVA6 and $43 \%$ for CVA10 in healthy children aged 4-6, China [24]. In our study, the positive rate of neutralizing antibodies was $66.7 \%$ for CVA6 and $26.7 \%$ for CVA10 in cases, while $66.7 \%$ for CVA6 and $50.0 \%$ for CVA10 in healthy children. The high positively rates probably caused by the concentration of Hand-foot-andmouth disease within two months before the onset of the disease, which also supported our conclusion. Reports about the mechanism of onychomadesis after HFMD were limited. Onychomadesis may occur after inflammation of the nail matrix or maceration associated finger blisters because of traumatic nail loss [19]. The shed nail fragments of a patient who suffered onychomadesis after HFMD were positive for CVA6 nucleic acid test in an outbreak of onychomadesis, which suggested that CVA6 virus replication caused the damage of nail matrix, resulting in onychomadesis [12]. HFMD outbreak frequently occurs in kindergarten, but there were few reports of onychomadesis outbreak in China [17, 18]. The pathogens of the HFMD kept drifting in different countries [25-30]. The EV71 inactivated vaccine successfully entered the market in China since June
2016 [31]. Other enterovirus (except EV71 and CVA16) in the confirmed cases of HFMD were the predominate pathogen (accounted for 76\%) in Hubei province in 2017, which was different from the past pathogen trends and showed the change of major pathogen [20, 21]. An outbreak of HFMD in 2016 showed that the positive rate was $76 \%(146 / 192)$ for CVA6 and $2.6 \%$ for CVA10 in Chongqing [32]. In our study, the HFMD outbreak before onychomadesis outbreak only affected Primary Class \#2 by the passive and active surveillance in Kindergarten $\mathrm{H}$, which may related to the contact transmission. Our study is the first reported onychomadesis outbreak in Hubei province and it was rare in China, which means further research is necessary to learn about its etiology, epidemic trend, prevention and control, and the relationship with onychomadesis. There are several limitations in our study. The positive rate of HFMD nucleic acid test was low, and the results of neutralizing antibody test only suggested previous infection. The HFMD nucleic acid test was delayed and we collected anal swabs rather than feces or shed nail described in previous literatures $[10,12,13]$. The results of zero prevalence of HFMD virus in anal swabs by using nucleic acid tests were predictable regarding the clearance of HFMD virus after recovery. In addition, we only tested the neutralizing antibodies CVA6 and CVA10 which were common pathogens related to onychomadesis. The emergency stocks of the neutralizing antibodies for HFMD were insufficient. The surveyed pathogenic types of HFMD were EV71, CVA16 and other enteroviruses, and further classification of other enteroviruses was not official requirement yet in Hubei province.

\section{Conclusions}

In conclusion, the first onychomadesis outbreak occurred in Hubei province was probably associated with HFMD epidemic within two months after onset.

\section{Supplementary information}

Supplementary information accompanies this paper at https://doi.org/10. 1186/s12879-019-4560-8.

Additional file 1: Table S1. Results of blood and environment tests in Kindergarten $H$, Hubei province, 2017.

\section{Abbreviations}

CDC: Center for Disease Control and Prevention; Cl: Confidence Interval; CVA10: Coxsackie virus A10; CVA16: Coxsackie virus A16; CVA5: Coxsackie virus A5; CVA6: Coxsackie virus A6; CVB1: Coxsackie virus B1; CVB2: Coxsackie virus B2; E9: Enterovirus 9; EV71: Enterovirus71; HFMD: Hand-foot-mouth disease; RT-PCR: reverse transcriptase-polymerase chain reaction; VP1: Viral protein 1; RR: Rate Ratio

\section{Acknowledgements}

We thank Wuhan pediatric hospital, Wuhan institute of biological products and Songzi prefecturual Center for disease control and prevention for their 
strong support in this investigation. We thank Dr. Tao Li (Chinese Center for Disease Control and Prevention) for the editing help.

\section{Authors' contributions}

$X G$, and SG contributed to study design; YW, XX, JH, AM, TL, PR, WQ, LZ, LF and $\mathrm{DL}$ participated in the investigation and data collection; $\mathrm{DL}, \mathrm{YW}$, and $\mathrm{XX}$ analyzed the results; DL drafted the manuscript. All authors read and approved the final manuscript.

\section{Funding}

Not applicable

\section{Availability of data and materials}

The datasets used and/or analysed during the current study available from the corresponding author on reasonable request.

\section{Ethics approval and consent to participate}

Outbreak investigation was a part of CDC's routine responsibilities and formal ethics approval was not required according to the law of the People's Republic of China on prevention and control of infectious disease (revised in 2013). We obtained written informed consents from parents of patients during the outbreak investigation.

\section{Consent for publication}

Not applicable

\section{Competing interests}

The authors declare that they have no competing interests.

\section{Author details}

'Division of Infectious Disease, Jingmen Center for Disease Control and Prevention, Jingmen 448000, Hubei, China. ²Division of Infectious Disease, Hubei Provincial Center for Disease Control and Prevention, Wuhan 430079, China. ${ }^{3}$ Chinese Field Epidemiology Training Program, Beijing 100050, China ${ }^{4}$ Division of Infectious Disease, Jingzhou Center Disease Control and Prevention, Jingzhou 434000, Hubei, China. ${ }^{5}$ Jingmen Municipal Commission of Health and Family Planning, Jingmen 448000, Hubei, China. 'Lu'an Center Disease Control and Prevention, Lu'an 237008, Anhui, China. ${ }^{7}$ Division of Infectious Disease, Chinese Center for Disease Control and Prevention, Key Laboratory of Surveillance and Early-warning on Infectious Disease, Beijing 102206, China

\section{Received: 12 July 2018 Accepted: 15 October 2019}

Published online: 26 November 2019

\section{References}

1. James WD, Berger TG, Elston DM (2005). Andrews' diseases of the skin: clinical dermatology. (10th ed.). Saunders. ISBN 0-7216-2921-0.

2. Freedberg IM, Eisen AZ, Wolff K, Austen KF, Goldsmith LA, Katz SI, et al. (2003). Fitzpatrick's dermatology in general medicine. (6 ${ }^{\text {th }}$ ed.). McGraw-Hill. ISBN 0-07-138076-0.

3. Salazar A, Febrer I, Guiral S, Gobernado M, Pujol C, Roig J. Onychomadesis outbreak in Valencia, Spain, June 2008. Euro Surveill. 2008;13(27):18917.

4. Clementz GC, Mancini AJ. Nail matrix arrest following hand-foot-mouth disease: a report of five children. Pediatr Dermatol. 2000;17(1):7-11.

5. Bernier $V$, Labreze C, Bury F, Taieb A. Nail matrix arrest in the course of hand, foot and mouth disease. Eur J Pediatr. 2001;160:649-51.

6. Redondo Granado MJ, Izquierdo B. Brote de onicomadesis posvírica en Valladolid. An Pediatr (Barc). 2009:71:436-9.

7. Cabrerizo M, De Miguel T, Armada A, Martinez-Risco R, Pousa A, Trallero G. Onychomadesis after a hand, foot, and mouth disease outbreak in Spain, 2009. Epidemiol Infect. 2010;138:1775-8.

8. Guimbao J, Rodrigo P, Alberto MJ, Omenaca M. Onychomadesis outbreak linked to hand, foot, and mouth disease, Spain, July 2008. Euro Surveill. 2010;15:19663

9. Davia JL, Bel PH, Ninet VZ, Bracho MA, Gonzalez-Candelas F, Salazar A, et al. Onychomadesis outbreak in Valencia, Spain associated with hand, foot, and mouth disease caused by enteroviruses. Pediatr Dermatol. 2011;28:1-5.

10. Bracho MA, González-Candelas F, Valero A, Córdoba J, Salazar A. Enterovirus co-infections and onychomadesis after hand, foot, and mouth disease, Spain, 2008. Emerg Infect Dis. 2011;17(12):2223-31.
11. Navarro Moreno E, Almagro López D, Jaldo Jiménez R, Del Moral Campaña MC, Árbol Fernández G, Pérez Ruiz M, et al. Outbreak of hand, foot and mouth disease with onychomadesis caused by Coxsackie virus A16 in Granada. An Pediatr (Barc). 2015:82(4):235-41.

12. Osterback R, Vuorinen T, Linna M, Susi P, Hyypia T, Waris M. Coxsackievirus A6 and hand, foot, and mouth disease. Finland Emerg Infect Dis. 2009:15:1485-8.

13. Blomqvist S, Klemola P, Kaijalainen S, Paananen A, Simonen ML, Vuorinen $T$, et al. Co-circulation of coxsackieviruses A6 and A10 in hand, foot and mouth disease outbreak in Finland. J Clin Virol. 2010;48(1):49-54.

14. Wei SH, Huang YP, Liu MC, Tsou TP, Lin HC, Lin TL, et al. An outbreak of coxsackievirus A6 hand, foot, and mouth disease associated with onychomadesis in Taiwan, 2010. BMC Infect Dis. 2011;11:34

15. Apalla Z, Sotiriou E, Pikou O, Lefaki I, Lallas A, Lazaridou E, et al. Onychomadesis after hand-foot-and-mouth diseaseoutbreak in northern Greece: case series and brief review of the literature. Int J Dermatol. 2015; 54(9):1039-44

16. Miyamoto A, Hirata R, Ishimoto $K$, Hisatomi M, Wasada R, Akita $Y$, et al. An outbreak of hand-foot-and-mouth diseasemimicking chicken pox, with a frequent association of onychomadesis in Japan in 2009: a new phenotype caused by coxsackievirus A6. Eur J Dermatol. 2014;24(1):103-4.

17. Kao QJ, Sun Z, Zhou XH, Shou J, Zhang GZ, Xi SJ, et al. An outbreak of coxsackievirus A6 hand, foot, and mouth disease associated with onychomadesis in Hangzhou. Prev Med. 2016;28(12):1239-1242,1245 (In Chinese).

18. Li J, Zhu R, Huo D, Du Y, Yan Y, Liang Z, et al. An outbreak of Coxsackievirus A6-associated hand, foot, and mouth disease in a kindergarten in Beijing in 2015. BMC Pediatr. 2018;18(1):277.

19. Haneke E. Onychomadesis and hand, foot and mouth disease--is there a connection? Euro Surveill. 2010;15(37):19664.

20. Xing W, Liao Q, Viboud C, Zhang J, Sun JL, Wu JT, et al. Hand, foot, and mouth disease in China, 2008-12: an epidemiological study. Lancet Infect Dis. 2014:14(4):308-18.

21. Chen Q, Dong XC, Sun ML. Epidemiological features of hand, foot and mouth disease in Tianjin, 2013-2014. Disease surveillance. 2015;30(06):463-7 (In Chinese).

22. BJ LV, Cheng H, Yang XB, Chen WE. Epidemiological features of hand, foot and mouth disease from 2010 to 2015 in Liuzhou city of China. Chin J Viral Dis. 2018;2:124-9 (In Chinese).

23. van der Sanden SM, Hetty van Eijk GK, Koekkoek SM, de Jong MD, Wolthers KC. Prediction of protection against Asian Enterovirus 71 outbreak strains by cross-neutralizing capacity of serum from Dutch donors, the Netherlands. Emerg Infect Dis. 2016;22:1562-9.

24. Zhu R, Cheng T, Yin ZC, Liu DX, Xu LF, Li YC, et al. Serological survey of neutralizing antibodies to eight major enteroviruses among healthy population. Emerg Microbes Infect. 2018;7(1):2.

25. Horwood PF, Alessio A, Arnaud T, Henrik S, Veasna D, Channa M, et al. Seroepidemiology of human Enterovirus 71 infection among children. Cambodia Emerg Infect Dis. 2016;22:92-5.

26. Montes M, Juncal A, Luis DP, Marina G, Inmaculada DN, Gustavo C, et al. Hand, foot, and mouth disease outbreak and coxsackievirus A6, northern Spain, 2011. Emerg Infect Dis. 2013;19:676-8.

27. Lu QB, Zhang XA, Wo Y, Xu HM, Li XJ, Wang XJ, et al. Circulation of Coxsackievirus A10 and A6 in hand-foot-mouth disease in China, 20092011. PLoS One. 2012;7:e52073.

28. Fujimoto T, Setsuko I, Miki E, Katsuhiko A, Kazuyo Y, Nozomu H, Nobuhiko O, et al. Hand, foot, and mouth disease caused by coxsackievirus A6, Japan, 2011. Emerg Infect Dis. 2012;18:337-9.

29. Puenpa J, Chieochansin T, Linsuwanon P, Korkong S, Thongkomplew S, Vichaiwattana P, et al. Hand, foot, and mouth disease caused by coxsackievirus A6, Thailand, 2012. Emerg Infect Dis. 2013;19:641-3.

30. Hayman R, Shepherd M, Tarring C, Best E. Outbreak of variant hand-footand-mouth disease caused by coxsackievirus A6 in Auckland. New Zealand J Paediatr Child H. 2014:50:751-5.

31. China center for disease control and prevention. Technical guide for the use of inactivated enterovirus 71 vaccine. 2016-06-08. http://www.chinacdc.cn/ zxdt/201606/t20160608 131032.html. Access on 2016-06-11.

32. Tao J, He XY, Shi Y, Zhu GH, Liu S, Zhang ZZ, et al. Epidemiology of 45,616 suspect cases of Hand, Foot and Mouth Disease in Chongqing, China, 2011 2015. Sci Rep. 2017;7:45630.

\section{Publisher's Note}

Springer Nature remains neutral with regard to jurisdictional claims in published maps and institutional affiliations. 